\title{
Employers' Expectations of University Graduates as They Transition into the Workplace
}

\section{Michael Cheang}

Associate Professor, University of Hawaii at Manoa

Georgia Lynn Yamashita

Internship Instructor, University of Hawaii at Manoa

\begin{abstract}
Research on work readiness indicates employers are increasingly pointing out that soft skills are as important as discipline specific knowledge and technical skills when hiring recent university graduates. However, many university students think excellent grades are the main reason they get the jobs. The disconnect between what employers expect and what students imagine is significant to the extent that many recent university graduates are unable to be employed in the jobs they want, and many employers have challenges dealing with recent university graduates who are not work ready. In 2018, a soft skills pilot study was conducted with internship supervisors who work with the Human Development and Family Studies Program at the University of Hawaii at Manoa. An online survey was sent to 65 internship supervisors, and three focus group sessions were conducted as a follow-up of the survey. In 2019, Phase 2 of this study polled 76 employers who participated in a university career fair on what soft skills they expect university graduates to have at the time of hiring. This paper reports on findings to two questions: 1) What employers think of undergraduate university students who have completed an internship with them, and 2) What soft skills employers expect of recent university graduates who are transitioning into the workplace. Findings indicate that in addition to soft skills, employers also regard personal attributes and qualities as equally important at the time of hire.
\end{abstract}

Keywords: Soft Skills, Employability Skills, Work Readiness

\section{Introduction}

Many recent university graduates assume that excellent or good grades will significantly increase their likelihood of securing a job of their choice. While this may be true in the first rounds of screenings as employers examine whether job applicants meet minimum requirements, evidence suggests that employers are increasingly expecting more than academic knowledge and technical expertise when hiring job applicants (Robles, 2012). In fact, evidence in the research literature suggests that employers regard soft skills as important as academic training and technical know-how when considering which job applicants to employ (Heckman \& Kautz, 2012; Levin, 2012). 
Soft skills are the series of skills that are necessary in order for an employee to be functional and effective in the workplace (Gross \& Latham, 2012). Examples include problem solving and critical thinking skills (Dean \& East, 2019; U.S. Department of Labor, 2012). Soft skills also include the people skills like having the ability to get along with others in the office, being a part of a team, and knowing how to communicate properly, effectively and respectfully in writing, orally, virtually, and non-verbally.

Besides soft skills, employers also regard personal attributes as equally important in order for an individual to be work ready. These personal attributes include having a sense of empathy, being respectful of others, and having a sense of responsibility. Other examples of personal attributes include being punctual, having integrity, and having a good work ethic.

Some employers also point out that it is not just about having the technical know-how and the qualities and traits, but also that certain traits increase the goodness of fit between the individual applying for a job and the people in the workplace (as opposed to the goodness of fit to the job). Such personal attributes may include being flexible, having a good attitude, and the willingness to go beyond one's usual call of duty (Liptak, 2005).

\section{Literature Review}

From a student's perspective, a university education may be regarded as a time for the acquisition of knowledge and technical knowhow in preparation for a job and a career. From an employer's perspective, a university education is also a time to prepare students to be ready for the workplace (Pereira \& Costa, 2017; NCIHE, 1997).

Research on work readiness point out how important it is to have the necessary skills that a person needs to have in order to do a job, especially when the job requires specific or special training. Some of these skills include knowing how to analyze data using a certain computer software, knowing how to assess if a child is abused based on standardized assessment tests, or determining if an adolescent is at high risk for teen dating violence. On the other hand, soft skills and personal attributes enable a person to get along and work with others in the workplace. These are the generic, people skills that are necessary in order for employees to be effective and functional in the workplace no matter what the discipline or nature of work is.

In their study, Cunningham and Villaseñor (2016) examined a sample of 27 studies and found a remarkable consistency across the world in the skills demanded by employers. Cunningham and Villaseñor discovered that while employers value all skill sets, there is a greater demand for socio-emotional skills and higher-order cognitive skills than for basic cognitive or technical skills, and that these results are robust across region, industry, occupation, and education level (2016).

Other researchers have also indicated that soft skills and personal attributes are as important as hard skills in various other fields of work or industries. For example, employers in the fields of nursing (Ng, 2020), engineering (Shekhawat \& Bakilapadavu, 2017; Lear, 2011; Thilmany, 2009) and accounting (Ghani, Rappa \& Gunardi, 2018) regard soft skills and personal attributes as important as hard skills. Similarly, the National Aeronautics and Space Administration (NASA) in the U.S., has found it necessary to help its scientists, engineers and their project teams to build soft skills because they recognize soft skills as factors that help improve communication, performance and morale for their technical teams. These skills are regarded as critical to the success of their missions (Pellerin, 2009). 
More recently, Google's in-house research project on hiring, firing, and promotion found that among the eight most important qualities of Google's top employees, STEM (science, technical, engineering and mathematics) skills were the least of the important skills (Strauss, 2017). The other seven most important qualities of Google's top employees were all soft skills: Being a good coach, communication skills, possessing insights into others and different values and points of view, empathy toward one's colleagues, critical thinking, problem solving, and drawing conclusions and making connections across complex ideas.

Employers are beginning to recognize the significance of people skills and personal attributes, and how they affect or contribute to a quality of life in the workplace, especially when people spend as much as one third of their day (or life) in the workplace. Soft skills and personal attributes may not only determine the quality of relationships in the workplace, but may also affect productivity and morale. Other researchers have also discovered how soft skills may be predictors of workplace and career success (Liptak, 2018).

Perhaps most notable of all is that some recent university graduates inaccurately think that they have the soft skills in order to be successful in a job search and in the workplace because they had taken writing and public speaking courses at the university. On the contrary, there is a disconnect between what students and recent graduates think, and what employers know and have experienced (Shivpuri \& Kim, 2004). According to a study done by the American Association of Colleges and Universities (AACU), 500 hiring managers, or non-executives (directors, managers, supervisors, and office administrators) whose current job responsibilities include recruiting, interviewing, and/or hiring new employees) indicated that while the following skills are regarded as very important for the workplace, less than half of recent university graduates are prepared (2018). The soft skills that the 500 hiring managers said recent university graduates lack include the ability to communicate effectively orally and in writing, critical thinking and analytical reasoning abilities, the ability to find, organize, evaluate information from multiple sources, and the ability to work independently (AACU, 2018).

\section{Methodology}

This descriptive study has two components. The first component is an online survey using a purposeful sampling of internship site supervisors and three follow up focus group sessions regarding their assessments of the students who have completed a 180 hours internship program at their agency.

Undergraduate students in the Human Development and Family Studies Program at the University of Hawaii at Manoa are required to complete a 180-hour internship at a community site. The purpose of the internship is to provide students with a bridge between theory and practice. During the internship that spans the course of one semester (approximately 4 months), students are placed at community sites for 12 hours a week. The students get to shadow agency employees and given responsibilities to carry out tasks as guided by the internship supervisors.

The 25-question online survey was sent to 66 internship site supervisors asking them to rate the student interns' academic and technical knowledge, communication skills (writing, verbal, listening), and personal attributes (work ethic, emotional intelligence). Rating of the student interns' knowledge, skills, and personal attributes was done on a Likert Scale (4 = Excellent, 3 
= Good, 2 = Average, 1 = Unsatisfactory). A total of 32 out of 66 supervisors completed the survey with a response rate of 48 percent.

Three follow up focus group sessions were conducted with a total of 18 supervisors. The focus group participants were given a summary of the online survey results, and were asked to comment on these findings. The purpose of the focus groups was to collect more in-depth information and to determine if the responses from the focus groups would validate the findings from the online survey.

The second component of the study is a student poll of employers who participated in a university career fair. Twenty-eight students in a university soft skills class were required to attend a university career fair that had been organized by the university career center. During this on-campus career fair visit, the students were asked to approach at least three employers and ask what soft skills and personal attributes the employers would look for when hiring recent university graduates. A total of 76 employers participated in this career fair. The employers come from the private sector, non-profits, and federal, state and county government agencies.

\section{Analysis}

Data from the online survey were compiled for frequencies and tabulated. The mean and standard deviation values for number of years of the survey respondents have worked in this occupation, and the mean years this person has worked in a supervisory or in a more senior position (manager, director, administrator) were calculated as part of the descriptive statistics. Mean scores and standard deviation values were also calculated for the ratings that the supervisors gave of the students who interned at their agencies.

Data from the focus groups were transcribed and reviewed for themes that emerged. The review of the focus group data was done separately by the two investigators to account for inter-rater reliability.

Data from the career fair was compiled and grouped into categories as the themes emerged. The frequencies of the skills and personal attributes were then recorded and percentages calculated.

\section{Results}

Three quarters of the survey respondents are females, and about 65 percent of the respondents are 41 years of age and older (Table 1). More than half (62 percent) of the online survey respondents have worked in their occupations for 10 years or longer. Approximately 40 percent of the respondents have worked for over 20 years. The longest that a survey respondent has worked is 40 years, while the most junior of the respondents has only worked for one year.

Table 1. Descriptive Statistics of Survey Respondents

$$
\mathrm{n}=32
$$

Females $=24$

\begin{tabular}{|c|c|c|c|c|c|}
\hline Age Group & $25-30$ years & $31-40$ years & $41-50$ years & $51-60$ years & $61-70$ years \\
\hline Females & 2 & 4 & 7 & 7 & 4 \\
\hline Males & 1 & 4 & 2 & 1 & - \\
\hline Total & 3 & 8 & 9 & 8 & 4 \\
\hline
\end{tabular}




\begin{tabular}{|c|c|c|c|c|}
\hline & Mean (years) & STD (years) & $\begin{array}{c}\text { Max (years } \\
\text { worked) }\end{array}$ & $\begin{array}{c}\text { Min (Years } \\
\text { worked) }\end{array}$ \\
\hline $\begin{array}{c}\text { Years worked in this } \\
\text { occupation }\end{array}$ & 13.6 & 9.7 & 40 & 1 \\
\hline $\begin{array}{c}\text { Years as a supervisor or } \\
\text { higher }\end{array}$ & 12.2 & 8.7 & 35 & 1 \\
\hline
\end{tabular}

Type of Organization Survey Respondents Work at. $\mathrm{n}=32$

\begin{tabular}{|c|c|c|}
\hline Type of Organization & Frequency & Percent \\
\hline Government & 9 & 28.12 \\
\hline Non-Profit & 19 & 59.37 \\
\hline For Profit & 2 & 6.25 \\
\hline $\begin{array}{c}\text { Other: (e.g., Hospital, } \\
\text { university) }\end{array}$ & 2 & 6.25 \\
\hline Total & 32 & 100 \\
\hline
\end{tabular}

Table 2. Online Survey Internship Supervisors' Ratings of Student Interns

4 = Excellent, 3 = Good, 2 = Average, 1 = Unsatisfactory

\begin{tabular}{|c|c|c|}
\hline Survey Item & Mean Score & SD \\
\hline Keeps disruptive emotions and impulses in check & 3.38 & 0.55 \\
\hline Maintains standards of honesty and integrity & 3.34 & 0.60 \\
\hline Strives to improve or meet a standard of excellence & 3.16 & 0.63 \\
\hline Aligns with the goals of the organization & 3.13 & 0.55 \\
\hline Takes responsibility for personal performance & 3.06 & 0.67 \\
\hline Demonstrates flexibility in handling change & 3.06 & 0.72 \\
\hline Works at nurturing important relationships & 2.88 & 0.61 \\
\hline Bolsters the abilities of others & 2.75 & 0.72 \\
\hline $\begin{array}{c}\text { Writes clearly in an organized, grammatically correct } \\
\text { manner }\end{array}$ & 2.75 & 0.62 \\
\hline Knows her or his strengths and limits & 2.69 & 0.64 \\
\hline $\begin{array}{c}\text { Writes appropriately in style, content for intended } \\
\text { audience }\end{array}$ & 2.69 & 0.64 \\
\hline Initiates and manages change & 2.66 & 0.65 \\
\hline
\end{tabular}

Table 3. Career Fair Data Frequencies and Percent of Skills and Personal Attributes $\mathrm{n}=1,339$

\begin{tabular}{|c|c|c|}
\hline Soft Skills and Personal Attributes & Frequencies & $\begin{array}{c}\text { Frequencies } \\
\text { (Percent) }\end{array}$ \\
\hline Attitude and Work Ethic & 508 & 38 \\
\hline Communication Skills & 455 & 34 \\
\hline Critical Thinking and Problem-Solving Skills & 215 & 16 \\
\hline Work Well with Others & 161 & 12 \\
\hline Total & 1,339 & 100 \\
\hline
\end{tabular}

\section{Discussion}


Data from the survey indicate that about 35 percent of the survey respondents think that the student interns are not work ready. The employers place a high value on soft skills when seeking qualified job candidates, and almost 62 percent also said they are unlikely to hire recent university graduates who are academically strong but lacking soft skills.

The survey respondents rated the student interns good or better on 50 percent of the items listed in Table 2, while the student interns were rated between average and good for the other 50 percent of the items. While the internship supervisors rated the student interns relatively high on many items, the focus group sessions provided some very valuable insights to the contrary.

Overall, the students have much to improve with respect to what employers expect of new university graduates. The following are the themes that emerged from the focus group data: 1) Attitude and Work Ethic; 2) Communication Skills; 3) Critical Thinking and Problem-Solving Skills; and 4) Work Well with Others. These themes were also mirrored by responses from approximately 76 employers who were polled at a university career fair.

\section{Theme 1. Attitude and Work Ethic}

A crucial aspect of internship is being prepared before the start of the internship. Students are advised to find out as much as they can about the agency or organization that they would be interning at. Yet some students would either not make the effort to do this, they would do so in a cursory manner, or would wait too late to do the research before the start of the internship.

Supervisors frequently remarked that the intern arrived at the interview or at the start of the internship not being adequately informed about basic things like the agency's vision and mission, who they serve, and what services they provide.

The supervisors who participated in the focus group sessions stated that students often mistakenly regard the internship as temporary and inconsequential, and that student interns erroneously see themselves as helping the agency, rather than the agency providing them with valuable opportunities to get to know important things that students may not learn from classes taught in university classes. These important things may only be experienced in person on-site, and they include finding out about the dynamics of the office, personally meeting the clients that they serve, getting first hand experiences about the challenges of the profession, and meeting the partners in the network of service providers.

Sadly, the student interns sometimes view their roles without much commitment, which is evident in their attendance, punctuality, and completion of tasks with little regard and attention. The nonchalance with which students regard their internship opportunities and experience is surprising.

Having a positive attitude along with being personable and enthusiastic was also noted by the employers surveyed at the career fair as attributes they look for when hiring. This includes employees being pleasant and easy-going, and conducting themselves with confidence. Employers overwhelmingly stressed the importance of hiring and retaining employees with a strong work ethic; those who take initiative, are hard-working, and who work with integrity and commitment. Attributes such as being honest, punctual, reliable, and responsible were frequently mentioned. In addition, flexibility and adaptability were highly regarded, along with following directions and willingness to learn. This shows an overall regard for employees 
who have the attitude and desire to work hard at what they do, having almost an innate sense of what needs to be done, the importance of listening carefully to instructions and following the instructions properly, and having the persistence to carry out a task to completion.

\section{Theme 2. Communication Skills.}

The ability to communicate appropriately, in style, tone (writing, verbal, and listening), and in a timely manner, was also highly regarded, and yet these are skills that many interns lack. Employers at the career fair stressed that writing skills, including being able to write clearly with correct grammar, is something they look for when hiring. Expressing yourself clearly, and with confidence, when in front of others, were also stated as desirable attributes.

Supervisors gave numerous examples when student interns sent emails that were unprofessional-the emails did not address people properly and respectfully, were written with an informal style, or had grammatical errors. One supervisor remarked that "it is as if this intern was sending me a text message on her mobile phone like she would send a text message to her buddy."

Other forms of communication are the indirect, unintended forms of communication that occur frequently, and these are forms of communication that employers regard as important to be aware of and "big deals." These non-verbal forms of communication include dressing inappropriately for the workplace, a show of disinterest or lack of enthusiasm in their facial expressions, and texting on their mobile phones during staff meetings or during work hours. Clearly, employers expect recent university graduates to be mature with the self-awareness to refrain from engaging in such behaviors.

\section{Theme 3: Critical Thinking and Problem-Solving Skills.}

Critical thinking and problem-solving skills are an important part of interns' work performance, yet supervisors stated that interns often do not take the initiative to figure things out. This waiting for supervisors to give them all the answers poses an ongoing challenge for supervisors. It should be noted that problem solving was also mentioned by the employers polled at the career fair; more specifically, this included having the ability to think on your feet using critical and strategic thinking.

\section{Theme 4: Work Well with Others}

Not surprisingly, collaborating and working well with others, often defined as teamwork, was also one of the themes that emerged from the data. Employers expect recent university graduates to be thoughtful, mindful, flexible and helpful, and pointed out that many student interns do not have these qualities. Arguments can be made that these are learned behaviors and students can be taught to be more open minded, and be willing to extend a help to a coworker.

While this is a study on soft skills, it is becoming clear that skills are not only what employers are expecting recent university graduates to have; the data suggest that personal attributes like having a good attitude, a strong work ethic, and knowing how to be part of a team are as important as knowing how to carry out a task that requires technical or academic training. While skills can be taught and practiced, questions remain about whether the many personal attributes can be learned from becoming self-aware. As mentioned by one internship supervisor, "We would rather hire the attitude, and train the skills." 
Despite commenting on how some recent university graduates are not work ready, employers also recognize that many of these students are young, have little work or volunteer experience, and may have never worked full time. All that considered, employers still expect that in order to be work ready, students and recent university graduates need to be aware of the soft skills and personal attributes that make for a good fit between job applicant and not just the job, but also the workplace.

\section{Study Limitations}

This pilot study employed the use of convenience sampling to collect data. Hence, the findings are useful only to the extent as they reflect the perceptions and opinions of the study respondents, and it is inappropriate to generalize the findings of the study to a general population of students or employers.

The findings are interesting and useful insofar as getting a glimpse of what internship supervisors and employers in this sample expect of graduating students at the time of hire. Certain soft skills and personal attributes are not as tangible and distinct, making them difficult to define, quantify and measure. Therefore, the value of the findings of this study is limited to its use as a guide to refining or focusing our conversations between the university and the employers.

\section{Conclusion}

The findings of this study suggest that job search and career success may have little to do with IQ or academic knowledge. The findings also indicate that the idea of being work ready is not merely a matter of having soft skills, but also that personal attributes of the job applicant are equally, if not more, important than having the academic knowledge, technical know-how, and experience. Given that this is a pilot study, recommendations may not be appropriate until more studies can be completed.

Nonetheless, the data already point to the following as worthy of thoughtful considerations: 1) Universities play a pivotal role in preparing students to be work-ready, and should take the lead to ensure that students have the desirable skills and qualities that make them employable, and, in the long run, retainable, in order to achieve career success; 2) Increased partnership and collaboration between employers (or industry leaders) and university faculty to ensure that university graduates not only have the field-specific academic knowledge and training, but also the skills that are essential for career success at the time of hire.

\section{References}

[1] American Association of Colleges and Universities. (2018). Fulfilling the American Dream: Liberal Education and the Future of Work. Selected Findings from Online Surveys of Business Executives and Hiring Managers. Hart Research Associates. Washington, DC.

[2] Cunningham, W., \& Villaseñor, P. (2016). Employer Voices, Employer Demands, and Implications for Public Skills Development Policy Connecting the Labor and Education Sectors. The World Bank Research Observer, 31(1), 102-134.

[3] Dean, S., \& East, J. (2019). Soft Skills Needed for the 21st-Century Workforce. International Journal of Applied Management and Technology, 18(1). 
[4] Fabris, C. (2015). College Students Think They're Ready for the Work Force. Employers Aren't So Sure. The Chronicle of Higher Education, n/a. Retrieved from https://www.chronicle.com/article/College-Students-Think/151289

[5] Ghani, E., Rappa, R., \& Gunardi, A. (2018). Employers' Perceived Accounting Graduates' Soft Skills. Academy of Accounting and Financial Studies Journal, 22(5), 111.

[6] Gross, M. \& Latham, D. (2012). What's skill got to do with it?: Information literacy skills and self-views of ability among first-year college students. Journal of the American Society for Information Science and Technology. 63(3), 574-583.

[7] Heckman, J.J. \& Kautz, T. 2012). Hard evidence on soft skills. Labour Economics. 9(4), 451-464.

[8] Ingols, C. \& Shapiro,, M. (2014). Concrete Steps for Assessing the "Soft Skills" in an MBA Program. Journal of Management Education. 38(3),412-435.

[9] Kermis, G., \& Kermis, M. (2010). Professional Presence and Soft Skills: A Role for Accounting Education. Journal of Instructional Pedagogies, 2, 1-10.

[10] Kyllonen, P. C. (2008). The research behind the ETS Personal Potential Index (PPI). Princeton, NJ: Educational Testing Service.

[11] Landau, J. \& Meirovch, G. (2011). Development of students' emotional intelligence: participative classroom environments in higher education. Academy of Educational Leadership Journal. 15(3): 89-104.

[12] Lear, C. (2011). System administration soft skills. Communications of the ACM, 54(2), 52-58.

[13] Lee, K. S. \& Chen, W. H. (2017). A long shadow: Cultural capital, techno-capital and networking skills of college students. Computers in Human Behavior. 70,67-73.

[14] Levin, H. M. (2012). More than just test scores. Prospects: Quarterly Review of Comparative Education, 42, 269-284.

[15] Liptak, J. (2005). Using emotional intelligence to help college students succeed in the workplace. Journal of Employment Counseling, 42(4), 171-178.

[16] NCIHE (1997). Higher education in the learning society [Report of the National Committee of Inquiry into Higher Education: 'The Dearing Report']. Norwich: HMSO. Retrieved from https://bei.leeds.ac.uk/Partners/NCIHE/

[17] Ng, L. (2020). The perceived importance of soft (service) skills in nursing care: A research study. Nurse Education Today, 85, 104302.

[18] Orlando Petiz Pereira, \& Carlos Alberto A.T. Costa. (2017). The importance of soft skills in the university academic curriculum: The perceptions of the students in the new society of knowledge. International Journal of Business and Social Research, 7(6), 01-12.

[19] Pellerin, C. (2009). How NASA builds teams: Mission critical soft skills for scientists, engineers, and project teams. Hoboken, N.J: John Wiley \& Sons.

[20] Robles, M. (2012). Executive Perceptions of the Top 10 Soft Skills Needed in Today's Workplace. Business Communication Quarterly, 75(4), 453-465.

[21] Shekhawat, S., \& Bakilapadavu, G. (2017). Teaching Soft Skills to Engineering Students: A Case Study of BITS, Pilani. IUP Journal of Soft Skills, 11(1), 29-34.

[22] Shivpuri, S., \& Kim, B. (2004). Do employers and colleges see eye-to-eye? College student development and assessment. NACE Journal, 65, 37-44.

[23] Strauss, V. (2017, December). The surprising thing Google learned about its employees - and what it means for today's students. Washington Post. Retrieved 
from https://www.washingtonpost.com/news/answer-sheet/wp/2017/12/20/thesurprising-thing-google-learned-about-its-employees-and-what-it-means-fortodays-students/

[24] Thilmany, J. (2009). Nixing engineerese: communicating across departments calls for soft skills.(engineering management: Communicating with non-engineers.). Mechanical Engineering-CIME, 131(8).

[25] US Department of Labor, Office of Disability Employment Policy. (2012). Skills to Pay the Bills: Mastering Soft Skills for Workplace Success. Retrieved from https://www.dol.gov/odep/topics/youth/softskills/ 